\title{
Enhanced effects of cigarette smoke extract on inflammatory cytokine expression in IL-1 $\beta$ - activated human mast cells were inhibited by Baicalein via regulation of the NF- $\kappa$ B pathway
}

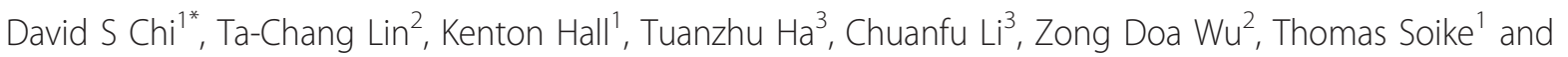
Guha Krishnaswamy

\begin{abstract}
Background: Human mast cells are capable of a wide variety of inflammatory responses and play a vital role in the pathogenesis of inflammatory diseases such as allergy, asthma, and atherosclerosis. We have reported that cigarette smoke extract (CSE) significantly increased IL-6 and IL-8 production in IL-1 $\beta$-activated human mast cell line (HMC-1). Baicalein (BAI) has anti-inflammatory properties and inhibits IL-1 $\beta$ - and TNF- $\alpha$-induced inflammatory cytokine production from HMC-1. The goal of the present study was to examine the effect of BAI on IL- 6 and IL-8 production from CSE-treated and IL-1 $\beta$-activated HMC-1.
\end{abstract}

Methods: Main-stream (Ms) and Side-stream (Ss) cigarette smoke were collected onto fiber filters and extracted in RPMI-1640 medium. Two $\mathrm{ml}$ of HMC-1 at $1 \times 10^{6}$ cells $/ \mathrm{mL}$ were cultured with CSE in the presence or absence of IL-1 $\beta(10 \mathrm{ng} / \mathrm{mL})$ for $24 \mathrm{hrs}$. A group of HMC-1 cells stimulated with both $\mathrm{IL}-1 \beta(10 \mathrm{ng} / \mathrm{ml})$ and CSE was also treated with BAI. The expression of IL- 6 and IL-8 was assessed by ELISA and RT-PCR. NF- $\kappa$ B activation was measured by electrophoretic mobility shift assay (EMSA) and $\mid \kappa B \alpha$ degradation by Western blot.

Results: Both Ms and Ss CSE significantly increased IL-6 and IL-8 production $(p<0.001)$ in IL-1 $\beta$-activated HMC-1. CSE increased NF- $\kappa$ B activation and decreased cytoplasmic $\mid \kappa B \alpha$ proteins in IL-1 $\beta$-activated HMC-1. BAI (1.8 to 30 $\mu M$ ) significantly inhibited production of IL-6 and IL-8 in a dose-dependent manner in IL-1 $\beta$-activated HMC-1 with the optimal inhibition concentration at $30 \mu \mathrm{M}$, which also significantly inhibited the enhancing effect of CSE on IL6 and IL-8 production in IL-1 $\beta$-activated HMC-1. BAI inhibited NF- $\kappa$ B activation and increased cytoplasmic $\mid \kappa B \alpha$ proteins in CSE-treated and IL-1 $\beta$-activated HMC-1.

Conclusions: Our results showed that CSE significantly increased inflammatory cytokines IL-6 and IL-8 production in IL-1 $\beta$-activated HMC-1. It may partially explain why cigarette smoke contributes to lung and cardiovascular diseases. BAI inhibited the production of inflammatory cytokines through inhibition of NF- $\kappa \mathrm{B}$ activation and $I \kappa \mathrm{B} \alpha$ phosphorylation and degradation. This inhibitory effect of BAI on the expression of inflammatory cytokines induced by CSE suggests its usefulness in the development of novel anti-inflammatory therapies.

Keywords: Mast cell, cigarette smoking, Baicalein, IL-6, IL-8, NF-kB activation, IKBa phosphorylation and degradation

\footnotetext{
* Correspondence: chi@etsu.edu

'Department of Internal Medicine, James H. Quillen College of Medicine,

East Tennessee State University, Johnson City, Tennessee 37614, USA

Full list of author information is available at the end of the article
} 


\section{Background}

Human mast cells, which are associated with allergies, asthma, and atherosclerosis, are multifunctional cells capable of inflammatory responses producing and secreting a wide variety of lipid mediators, histamine, cytokines, and chemokines [1,2]. Mast cells have been implicated in acute and chronic inflammatory responses and in many diseases characterized by inflammation [3]. The fact that mast cells accumulate at sites of inflammation, such as the nasal mucosa of patients with allergic rhinitis [4], the lung smooth muscle of patients with asthma [5], the skin of patients with urticaria [6], and the joints of patients with arthritis [7], illustrates the association of mast cells in these inflammatory diseases [8]. Our previous reviews have summarized the important role mast cells play in allergic, asthmatic, and inflammatory responses, conditions caused by the production of mediators and select inflammatory cytokines $[1,2]$.

Interleukin-6 (IL-6) and interleukin-8 (IL-8) are important inflammatory cytokines that are secreted from activated mast cells. IL- 6 is a multifunctional protein. In innate immunity, it stimulates the synthesis of acutephase proteins by hepatocytes and thus contributes to the systemic effects of inflammation [9]. In adaptive immunity, it stimulates the growth of B cells that have differentiated into antibody producers [10]. IL-8 is a potent neutrophil chemotactic and activating factor. It serves as a chemical signal that attracts neutrophils to the site of inflammation [11]. IL-1 $\beta$ is secreted mainly by macrophages. IL- $1 \beta$ is produced in response to various stimulants, such as bacteria, viruses, and cytokines [12]. Our previous studies have shown IL- $1 \beta$ activated human mast cells produce selected inflammatory cytokines $[13,14]$.

The Centers for Disease Control and Prevention reported that the adverse health effects from cigarette smoking account for an estimated 438,000 deaths or nearly 1 out of every 5 deaths each year in the United States. Cigarette smoking is linked to cancer, cardiovascular disease, respiratory disease, and other adverse effects. Epidemiological studies also show that cigarette smoking increases the risk of atherosclerosis [15]. Unfortunately, the underlying basic mechanisms involved in the processes that lead to diseases induced by cigarette smoke components is not much known. Previously, we have reported that cigarette smoke extract (CSE) significantly increased IL- 6 and IL- 8 production in IL- $1 \beta$-activated human mast cell-1 (HMC-1). The first goal of this study was to examine effects and mechanisms of CSE on the expression of inflammatory cytokines in mast cells. Studying mast cell responses to CSE may lead to a greater understanding of cigarette smoke induced diseases.
Baicalein (BAI) is a flavonoid originally isolated from the roots of the traditional Chinese herbal medicine Huangqin, Scutellaria baicalensis Georgi. It has been widely employed for many centuries in the traditional Chinese herbal medicine as popular antibacterial, antiviral, and anti-inflammatory agents [16]. Historically, Scutellaria baicalensis has been used to treat respiratory tract infection, diarrhea, jaundice, and hepatitis. Recent investigations showed it had broad anti-inflammatory activities. BAI suppressed the LPS-induced production of NO in RAW 264.7 mouse macrophages [17]. It was shown to have potent neuroprotective effect on LPSinduced injury of dopaminergic neurons [18]. Recently, BAI has been shown to inhibit inflammation through inhibition of COX-2 gene expression [19] and to suppress LPS induced degradation of $\mathrm{I} \kappa \mathrm{B} \alpha$ and activation of $\mathrm{NF}-\kappa \mathrm{B}[20]$. Recently, our group has reported that Baicalein inhibits IL-1 $\beta$ - and TNF- $\alpha$-induced inflammatory cytokine production from human mast cells via regulation of NF- $\kappa$ B pathway [21]. The second goal of this study is to investigate effects and mechanisms of BAI on inflammatory cytokine expressions from CSE treated and IL-1 $\beta$-activated human mast cells. Our results showed that BAI inhibited the enhanced effects of CSE on expression of inflammatory cytokines through inhibition of NF- $\kappa \mathrm{B}$ activation and $\mathrm{I} \kappa \mathrm{B} \alpha$ phosphorylation and degradation in human mast cells. This inhibitory effect of BAI on the expression of inflammatory cytokines suggests its usefulness in the development of novel antiinflammatory therapies.

\section{Methods \\ Reagents and cells}

The baicalein was purchased from Sigma (St. Louis, MO). The HMC-1 cell line, established from a patient with mast cell leukemia, was graciously provided by Dr. Joseph $\mathrm{H}$. Butterfield (Mayo Clinic, Rochester, MN). IL-1 $\beta$ and ELISA kits of IL-6, and IL-8 were purchased from R\&D (Minneapolis, MN). RPMI 1640 media and HEPES were obtained from GibcoBRL (Rockville, MD). 2-mercaptoethanol was purchased from Sigma (St. Louis, MO). Fetal bovine serum was obtained from Atlanta Biologicals (Atlanta, GA). RNA-BEE was purchased from Tel-Test, Inc. (Friendswood, Texas). Gene Amp RNA PCR Core Kit was purchased from Applied Biosystems (Branchburg, NJ).

\section{Cigarette smoke extract}

An ignited cigarette was placed in a $3.1 \mathrm{~L}$ bell-shaped glass vessel, the Sidestream smoke (Ss) within the vessel was pumped out of the bell and collected onto quartz fiber filters. Mainstream smoke (Ms) was collected directly from the cigarette onto quartz fiber filters using a puff volume of $35 \mathrm{ml}$ in 2 seconds at a rate of 8 puffs 
per minute. The filters were weighed before and after smoke collection and the increase in weight was recorded as cigarette smoke weight. The cigarette smoke was extracted from the filters with RPMI 1640 medium to a concentration of $5 \mathrm{mg} / \mathrm{ml}$.

\section{Cell culture}

HMC-1 cells were cultured and maintained in RPMI 1640 media with $5 \times 10^{-5}$ 2-mercaptoethanol, $10 \mathrm{mM}$ HEPES, gentamycin $50 \mu \mathrm{g} / \mathrm{ml}, 5 \mu \mathrm{g} / \mathrm{ml}$ insulin, transferrin and sodium selenite, $2 \mathrm{mM}$ L-glutamine, and $5 \%$ heat inactivated fetal bovine serum in a $37^{\circ} \mathrm{C}$ incubator with $5 \% \mathrm{CO}_{2}$. The cell cultures were maintained in $75 \mathrm{~cm}^{2}$ flasks (Corning) [22].

\section{Induction of cytokine production}

Two $\mathrm{ml}$ of HMC- 1 mast cells at $1 \times 10^{6}$ cells $/ \mathrm{ml}$ concentration were cultured with or without different concentrations of both Ms and Ss cigarette smoke extract in the presence or absence of IL-1 $\beta$ (10 ng/ml) for $24 \mathrm{hrs}$ [13]. A group of HMC-1 cells stimulated with both IL-1 $\beta$ (10 ng/ $\mathrm{ml}$ ) and CSE was also treated with BAI. The cultures were carried out in triplicate. At the end of incubation, supernatants were harvested for measuring IL- 6 and IL- 8 by ELISA and cell viability and numbers of the culture were analyzed. The cell viability was determined by trypan blue dye exclusion. Trypan blue dye (0.4\%) was added to cell samples in a ratio of 1:2.5 and preparations were viewed with a standard light microscope [13]. The ratio of live to dead cells (cell viability) was determined. The cell viabilities of the drug groups and the medium control cultures in this study were ranging from 90 to $98 \%$. BAI, IL-1 $\beta$, and CSE at the concentrations used in this study appeared to have no toxic effect to the HMC-1 cultures.

\section{ELISA for cytokine production}

Cytokine ELISA was performed for IL-6 and IL-8. ELISA was carried out on cell-free culture supernatants using commercially available ELISA kits, according to manufacturer's instructions as earlier described. Results were analyzed on an ELISA plate reader (Dynatech MR 5000 with supporting software) [13].

\section{Analysis of cytokine gene expression by RT-PCR}

HMC-1 were treated with the appropriate reagents and allowed to incubate at $37^{\circ} \mathrm{C}$ with $5 \% \mathrm{CO}_{2}$ for 6 hours before being harvested for RNA. RNA was extracted from HMC- $1\left(3 \times 10^{6}\right.$ cells $)$ by the addition of $1 \mathrm{ml}$ of RNA-BEE. After the addition of chloroform and shaking for 1 minute the samples were centrifuged at $12,000 \times \mathrm{g}$ for 15 minutes at $4^{\circ} \mathrm{C}$ to achieve phase separation. Isopropanol was added to the aqueous phase, and the preparation was frozen at $-20^{\circ} \mathrm{C}$ overnight. The following day, the samples were centrifuged at $12,000 \times \mathrm{g}$ for 30 minutes at $4^{\circ} \mathrm{C}$. The RNA pellet was washed with $1 \mathrm{ml}$ $75 \%$ ethanol containing DEPC and allowed to air dry. The pellet was resuspended in DEPC water and quantitated by optical density readings at $260 \mathrm{~nm}$. Reverse Transcriptase Polymer Chain Reaction (RT-PCR) was performed with a Gene Amp RNA PCR Core Kit according to manufacturer's instructions. cDNA was synthesized with murine leukemia virus reverse transcriptase $(2.5 \mathrm{U} / \mu \mathrm{l}), 10 \times$ PCR buffer $(500 \mathrm{mM} \mathrm{KCl}, 100 \mathrm{mM}$ Tris$\mathrm{HCl}, \mathrm{pH} 8.3), 1 \mathrm{mM}$ each of the nucleotides dATP, $\mathrm{dCTP}, \mathrm{dGTP}$ and dTTP; RNase inhibitor $(1 \mathrm{U} / \mu \mathrm{l}), \mathrm{MgCl}_{2}$ $(5 \mathrm{mM})$, and oligo $(\mathrm{dT})_{16}(2.5 \mu \mathrm{M})$ as a primer. The samples were incubated at $42^{\circ} \mathrm{C}$ for 20 minutes, $99^{\circ} \mathrm{C}$ for 20 minutes, and $5^{\circ} \mathrm{C}$ for 5 minutes in a DNA thermocycler (Perkin-Elmer Corp., Norwalk, CT) for reverse transcription. PCR of cDNA was done with $\mathrm{MgCl}_{2}(1.8 \mathrm{mM})$, each of the dNTPs $(0.2 \mathrm{mM})$, AmpliTaq polymerase (1 U/50 $\mu \mathrm{l})$, and paired cytokine-specific primers $(0.2 \mathrm{nM}$ of each primer) to a total volume of $50 \mu \mathrm{l}$. Cycles consisted of 1 cycle of $95^{\circ} \mathrm{C}$ for $2 \mathrm{~min}, 35$ cycles of $95^{\circ} \mathrm{C}$ for $45 \mathrm{sec}$, $60^{\circ} \mathrm{C}$ for $45 \mathrm{sec}$, and $72^{\circ} \mathrm{C}$ for $1 \mathrm{~min} 30 \mathrm{sec}$, and lastly, 1 cycle of $72^{\circ} \mathrm{C}$ for $10 \mathrm{~min}$. Ten microliters of the sample were electrophoresed on a $2 \%$ agarose gel and stained with ethidium bromide for viewing. Primer sequences used are as follows: HPRT: 5' CGA GAT GTG ATG AAG GAG ATG G 3' and 5' GGA TTA TAC TGC CTG ACC AAG G 3'; IL-6: 5' ATG AAC TCC TTC TCC ACA AGC GC 3' and 5' GAA GAG CCC TCA GGC TGG ACT G 3'; and IL-8: 5' ATG ACT TCC AAG CTG GCC GTG GCT 3' and 5' TCT CAG CCC TCT TCA AAA ACT TCT C 3'. Densitometry was done by normalizing target genes to house keepers using Un-Scan-It Version 5.1 software (Orem, UT) [21].

\section{$\mathrm{NF}-\kappa \mathrm{B}$ assay in HMC-1}

HMC-1 were stimulated with IL-1 $\beta$, CSE, and/or BAI for 30 minutes, and then harvested for isolation of nuclear and cytoplasmic proteins according our previously reported method [21]. Nuclear translocation of NF- $\kappa \mathrm{B}$ was analyzed by the electrophoretic mobility shift assay (EMSA) using the nuclear proteins [23-26]. Cells were washed with PBS and mixed with one hundred microliters of hypotonic buffer which contains: $10 \mathrm{mM}$ HEPES $\mathrm{pH}$ 7.9, $10 \mathrm{mM} \mathrm{KCl}, 0.1 \mathrm{mM}$ EDTA, $0.1 \mathrm{mM}$ EGTA, $1 \mathrm{mM}$ dithiothreitol (DTT), $0.5 \mathrm{mM}$ phenylmethylsulfonyl fluoride (PMSF), $1 \mu \mathrm{M}$ aprotinin, $1 \mu \mathrm{M}$ pepstatin, $14 \mu \mathrm{M}$ leupeptin, $50 \mathrm{mM} \mathrm{NaF}, 30 \mathrm{mM} \beta$-glycerophosphate, $1 \mathrm{mM}$ $\mathrm{Na}_{3} \mathrm{VO}_{4}$, and $20 \mathrm{mM}$ p-nitrophenyl phosphate. Cells were incubated over ice for 30 minutes and then vortexed after the addition of $6.25 \mu \mathrm{l}$ of $10 \%$ of Nonidet P-40. After 2 minutes of centrifugation at $30,000 \times \mathrm{g}$, supernatants were kept at $-80^{\circ} \mathrm{C}$ while the pellets were collected and vortexed every 20 minutes for 3 hours in $60 \mathrm{ml}$ of a hypertonic salt solution: $20 \mathrm{mM}$ HEPES pH 7.9, $0.4 \mathrm{M} \mathrm{NaCl}, 1 \mathrm{mM}$ 
EDTA, 1 mM EGTA, 12 mM DTT, 1 mM PMSF, $1 \mu \mathrm{M}$ aprotinin, $1 \mu \mathrm{M}$ pepstatin, $14 \mu \mathrm{M}$ leupeptin, $50 \mathrm{mM} \mathrm{NaF}$, $30 \mathrm{mM} \beta$-glycerophosphate, $1 \mathrm{mM} \mathrm{Na} \mathrm{VO}_{4}$, and $20 \mathrm{mM}$ p-nitrophenyl phosphate. Nuclear translocation of NF- $\kappa \mathrm{B}$ was analyzed by the EMSA using the nuclear fraction. Seven micrograms of nuclear protein were added to $2 \mathrm{ml}$ of binding buffer (Promega, Madison, WI), and $35 \mathrm{fmol}$ of double stranded NF- $\kappa$ B consensus oligonucleotide (5' AGT TGA GGG GAC TTT CCC AGG C 3') (Promega, Madison, WI) end labeled with $\gamma$-P32 ATP (Amersham Biosciences, Piscataway, NJ). The samples were incubated at room temperature for 20 minutes and run on a $5 \%$ nondenaturing polyacrylamide gel for 2 hours. A supershift assay using antibodies to P65 and P50 was performed to confirm NF- $\kappa$ B binding specificity as previously described [23-26].

\section{Western blot analysis for $\mathrm{I} \kappa \mathrm{B} \alpha$}

Cytoplasmic proteins $(40 \mu \mathrm{g})$ were mixed with $2 x$ SDS sample buffer, heated at $95^{\circ} \mathrm{C}$ for $5 \mathrm{~min}$, and separated by SDS-polyacrylamide (12.5\%) gel electrophoresis [24,27]. The separated proteins were transferred onto Hybond enhanced chemiluminescence membranes (Amersham) and then incubated with an appropriate rabbit primary antibody [I $\kappa \mathrm{B} \alpha$ antibody (Santa Cruz Biotechnology) or phosphorylated $\mathrm{I} \kappa \mathrm{B} \alpha$ antibody (New England Biolabs)] in Tris-buffered saline $-0.05 \%$ Tween 20 containing $5 \%$ nonfat dry milk for $1-2$ hours at room temperature. After they were washed three times in Tris-buffered saline $-0.05 \%$ Tween 20 , the membranes were incubated with peroxidase-conjugated goat anti-rabbit IgG (Sigma Chemical) for 1 hour at room temperature. After three washes in PBS, the conjugated peroxidase was visualized by enhanced chemiluminescence according to the manufacturer's instructions (Amersham). The protein signals of $\mathrm{I} \kappa \mathrm{B} \alpha$ were quantified by scanning densitometry (Genomic Solutions).

\section{Statistical analysis of the data}

All experiments were done in triplicate. The data were analyzed by Student's two-tailed $t$-test using Statistica software (StatSoft, Inc., Tulsa, OK). All data were reported as means \pm SE. A $p$-value of less than 0.05 was considered significant.

\section{Results}

CSE increased IL-6 and IL-8 production in IL-1 $\beta$-activated mast cells

HMC-1 cells were cultured with IL-1 $\beta(10 \mu \mathrm{g} / \mathrm{mL})$ and various concentration of CSE for 24 hours. The medium alone did not induce IL- 6 and IL-8 production in HMC-1 cells (Figures 1, 2, 3 and 4). As the previous report, IL-1 $\beta$ at $10 \mathrm{ng} / \mathrm{mL}$ concentration markedly induced IL-6 and IL8 production from $\mathrm{HMC}-1$, while the mainstream (Ms)

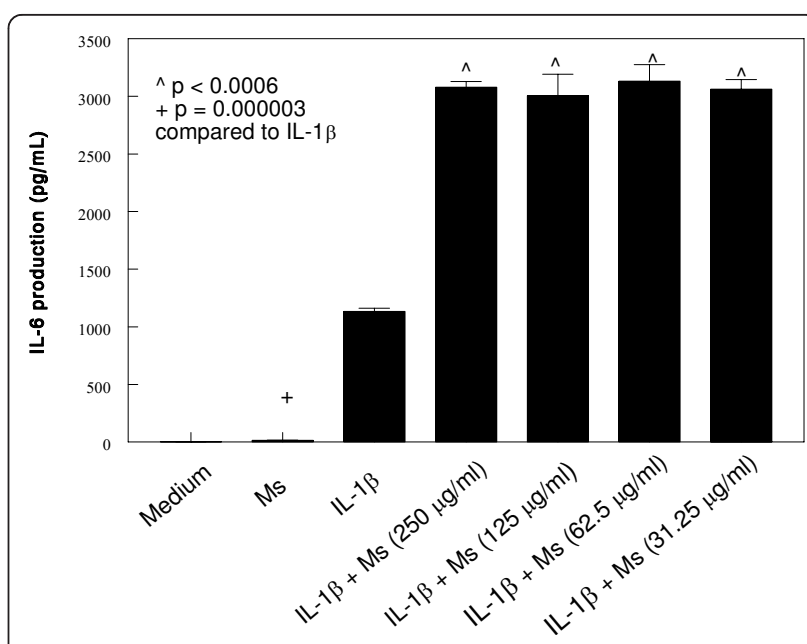

Figure 1 Effects of Mainstream cigarette smoke extract (Ms) on IL- 6 production from IL-1 $\beta$-activated HMC- 1 cells. To each well of a 6-well culture plate, two $\mathrm{ml}$ of HMC-1 $\left(1 \times 10^{6} \mathrm{cell} / \mathrm{s} / \mathrm{ml}\right)$ were cultured alone (Medium), or in the presence of $\mathrm{LL}-1 \beta(10 \mathrm{ng} / \mathrm{ml})$, and the combinations of IL-1 $\beta$ with different concentrations of Ms for 24 hrs in triplicate. Supernatants were harvested for measuring IL-6 by ELISA.

and sidestream (Ss) CSE either did not or only produced trace of cytokines (Figures 1, 2, 3 and 4). The effect of Ms CSE on production of IL- 6 was shown in Figure 1. The Ms CSE at 31.25 to $250 \mu \mathrm{g} / \mathrm{mL}$ concentrations significantly increased IL- 6 production in IL- $1 \beta$-activated HMC1 cells. The Ss CSE also increased production of IL- 6 in IL-1 $\beta$-activated HMC-1 cells (Figure 2). Similarly, both Ms and Ss CSE increased production of IL-8 in a dose-dependent fashion in IL-1 $\beta$-activated HMC-1 cells (Figures 3 and 4).

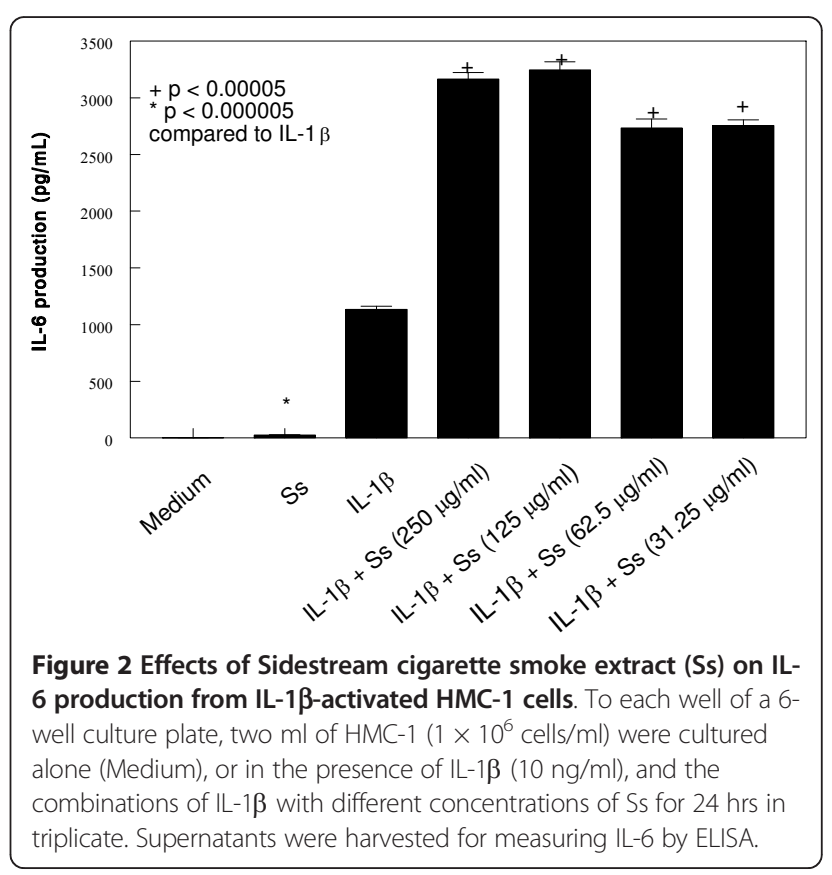




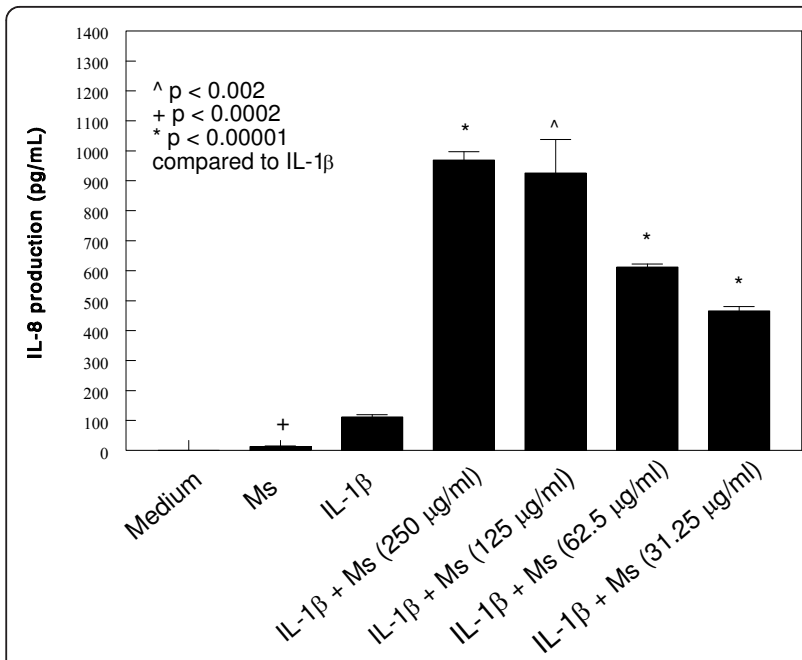

Figure 3 Effects of Mainstream cigarette smoke extract (Ms) on IL-8 production from IL-1 $\beta$-activated HMC-1 cells. To each well of a 6-well culture plate, two $\mathrm{ml}$ of HMC-1 $\left(1 \times 10^{6} \mathrm{cell} / \mathrm{s} / \mathrm{ml}\right)$ were cultured alone (Medium), or in the presence of IL-1 $13(10 \mathrm{ng} / \mathrm{ml})$, and the combinations of IL-1 $1 \beta$ with different concentrations of Ms for 24 hrs in triplicate. Supernatants were harvested for measuring IL-8 by ELISA.

BAI inhibits the enhancing effects of CSE on IL- 6 and IL-8 production in IL-1 $\beta$-activated mast cells

The effect of BAI on production of IL- 6 and IL- 8 from IL- $1 \beta$-activated HMC- 1 cells was studied. BAI at concentrations of $1.8,3.6,7.5,15$, and $30 \mu \mathrm{M}$ have been proved to be non-toxic to HMC-1 [28]. Two mL of HMC- 1 at $1 \times 10^{6}$ cells $/ \mathrm{mL}$ were cultured with the

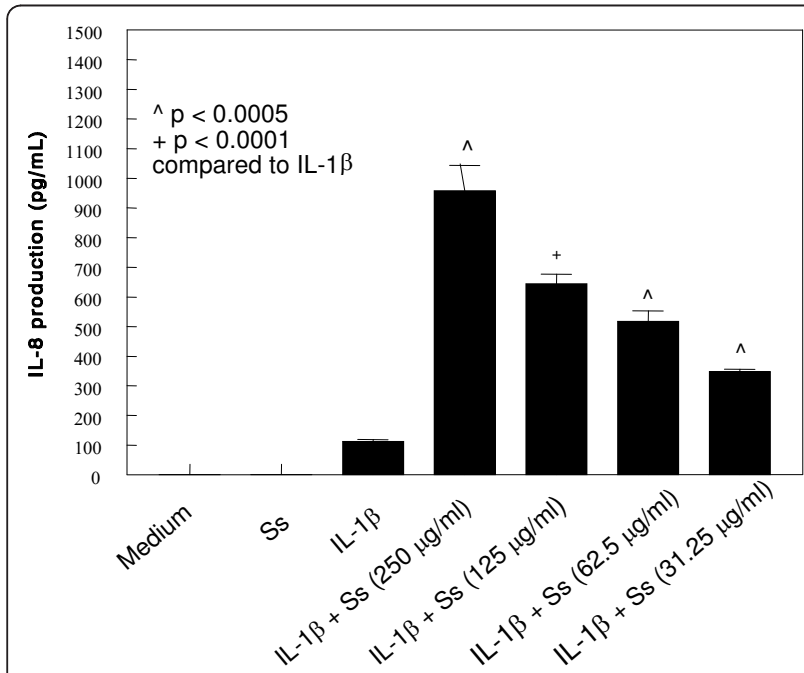

Figure 4 Effects of Sidestream cigarette smoke extract (Ss) on IL-8 production from IL-1 $\beta$-activated HMC-1 cells. To each well of a 6-well culture plate, two $\mathrm{ml}$ of HMC-1 $\left(1 \times 10^{6}\right.$ cells $\left./ \mathrm{ml}\right)$ were cultured alone (Medium), or in the presence of $\mathrm{IL}-1 \beta(10 \mathrm{ng} / \mathrm{ml})$, and the combinations of $\mathrm{IL}-1 \beta$ with different concentrations of Ss for 24 hrs in triplicate. Supernatants were harvested for measuring IL-8 by ELISA. above mentioned concentrations of BAI in the presence or absence of IL-1 $\beta$ (10 ng/mL) for $24 \mathrm{hrs}$. The culture supernatants were collected and assayed for cytokines by ELISA. BAI alone did not induce cytokine production from HMC-1. However, BAI at 15 and $30 \mu \mathrm{M}$ concentrations significantly decreased the IL- 6 production to $192.7 \pm 18.7$ and $74.6 \pm 14.6 \mathrm{pg} / \mathrm{mL}$, respectively $(\mathrm{p}<$ 0.0005 and $\mathrm{p}<0.00005$, respectively) (Figure 5A). BAI at all tested concentrations $(1.8$ to $30 \mu \mathrm{M})$ significantly decreased the IL- $1 \beta$-induced IL- 8 production, in a dosedependent manner, to $316.4 \pm 1.3,177.4 \pm 13.2,147.6 \pm$ $5.4,54.9 \pm 3.3$, and $46.9 \pm 4.4 \mathrm{pg} / \mathrm{mL}$, respectively $(\mathrm{p}<$ 0.05 for $1.8 \mu \mathrm{M}, \mathrm{p}<0.0005$ for $3.6 \mu \mathrm{M}$, and $\mathrm{p}<0.00005$ for all the rest) (Figure $5 \mathrm{~B}$ ). Since BAI at $30 \mu \mathrm{M}$ was the most effective concentration in inhibition of cytokine production in IL- $1 \beta$-activated $\mathrm{HMC}$ - 1 , we decided to only use this concentration in experiments with CSEtreated HMC-1.

In order to investigate the effect of BAI on the enhancing effects CSE has on IL- 6 and IL- 8 production in IL- $1 \beta$-activated mast cells, we treated the HMC- 1 cells with or without IL-1 $\beta$ and CSE in the presence or absence of BAI $(30 \mu \mathrm{M})$. BAI significantly inhibited the enhancing effect of both Ms and Ss CSE on production of IL- 6 in IL-1 $\beta$-activated HMC-1 (Figures 6 and 7).

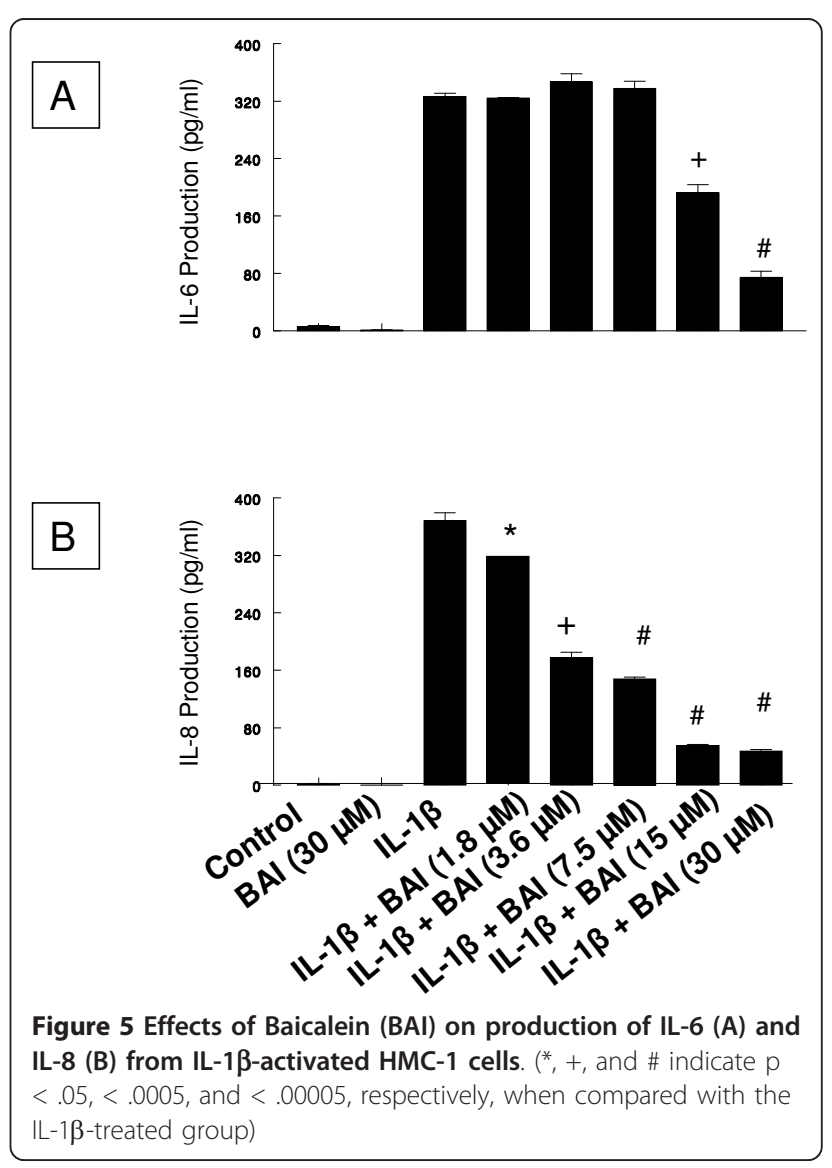


Similarly, BAI also significantly inhibited the enhancing effect of both Ms and Ss CSE on production of IL-8 in IL-1 $\beta$-activated HMC-1 (Figures 8 and 9).

Effects of BAI on IL-6 and IL-8 gene expressions in CSEtreated and IL-1 $\beta$-activated mast cells

To study effects of BAI on inflammatory cytokine gene expression, the experiments were performed using IL-1 $\beta$ activated HMC-1. HMC-1 were treated with IL-1 $\beta(10 \mu \mathrm{g} /$ $\mathrm{mL})$ and CSE in the presence or absence of BAI $(30 \mu \mathrm{M})$ for 6 hours and harvested for transcriptional analysis via RT-PCR. IL-1 1 -treated HMC-1 increased IL- 6 and IL-8 mRNA transcription (Figure 10). The intensities of the cytokine and house keeping gene (HPRT) bands were measured by densitometry, and the ratio of the cytokine to the house keeping gene was calculated and assigned as the intensity index. In the presence of Ms $(0.125 \mathrm{mg} / \mathrm{mL})$ or Ss $(0.125 \mathrm{mg} / \mathrm{mL}) \mathrm{CSE}$, the expression of IL-6 and IL-8 was increased. However, in the present of BAI, the expression of IL-6 and IL-8 was remarkably decreased (Figure 10).

Role of NF-kB activation in the inhibitory effect of BAI on inflammatory cytokine production from CSE-treated and IL-1 $\beta$-activated mast cells

$\mathrm{NF}-\kappa \mathrm{B}$ is an important transcription factor that mediates the transcription of many proinflammmatory cytokine genes $[29,30]$. In order to study the role that NF$\kappa \mathrm{B}$ plays in the inhibitory effect of BAI on inflammatory cytokine production, NF- $\kappa \mathrm{B}$ activation was analyzed in HMC-1 cultured with CSE and IL-1 $\beta(10 \mu \mathrm{g} / \mathrm{mL})$ in the presence or absence of BAI $(30 \mu \mathrm{M})$. NF- $\kappa \mathrm{B}$ translocation, as seen by a shift in oligonucleotide binding in EMSA gels, was increased in the IL- $1 \beta$-activated

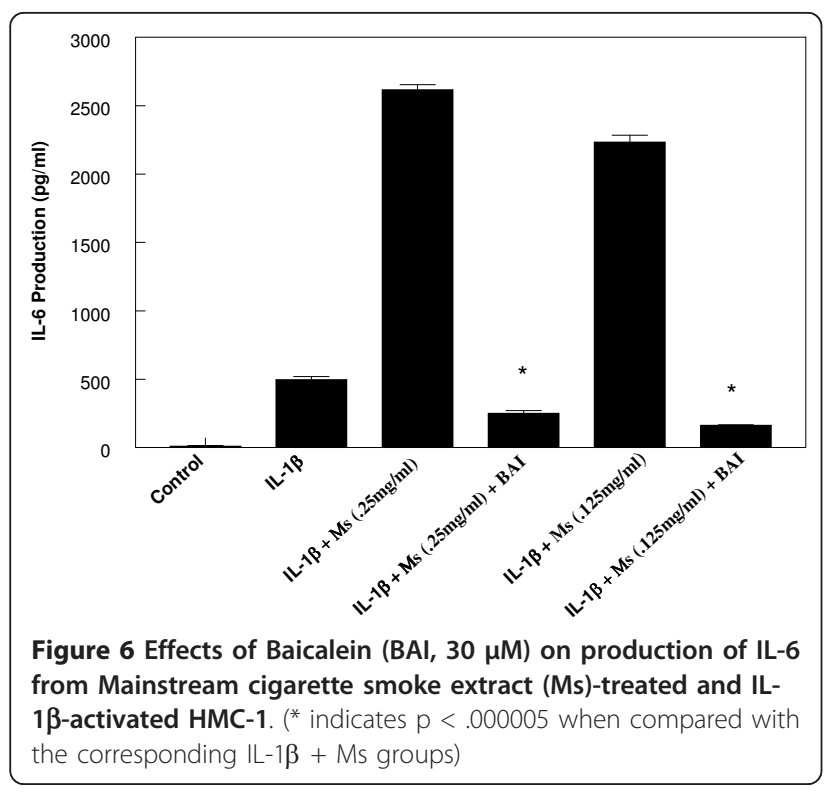

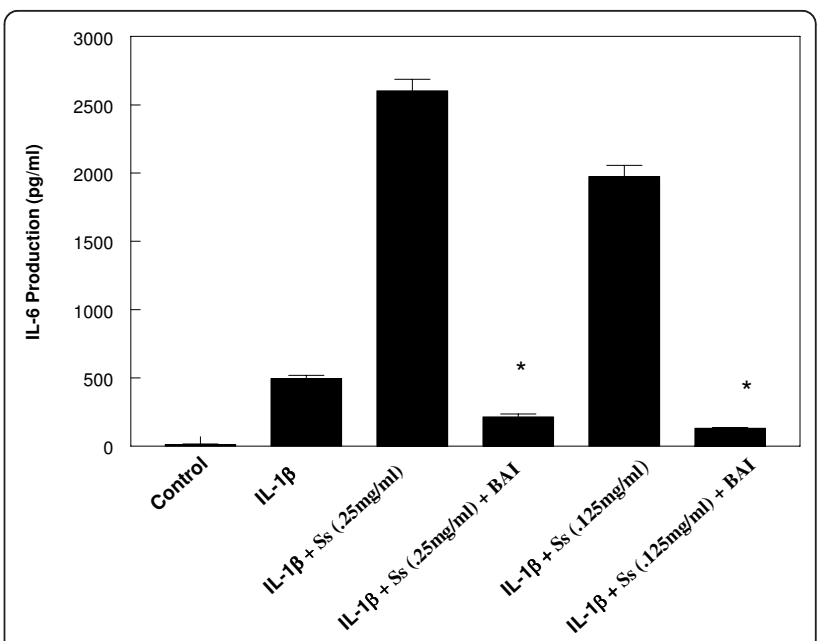

Figure 7 Effects of Baicalein (BAI, $30 \mu \mathrm{M}$ ) on production of IL-6 from Sidestream cigarette smoke extract (Ss)-treated and IL$1 \beta$-activated HMC-1. (* indicates $p<.00005$ when compared with the corresponding $\mathrm{IL}-1 \beta+$ Ss groups)

HMC-1 (Figure 11). With the addition of Ms or Ss CSE $(0.125 \mathrm{mg} / \mathrm{mL})$ treatment, NF- $\kappa \mathrm{B}$ translocation was even higher than that of the only IL-1 $\beta$-treated group (Figure $11)$. In the presence of BAI, NF- $\kappa \mathrm{B}$ translocation was decreased when compared to that of the IL-1 $\beta$ and CSE-activated HMC-1 (Figure 11).

Role of $\mathrm{IkB} \alpha$ proteins in the inhibitory effect of $\mathrm{BAI}$ on inflammatory cytokine production from CSE-treated and IL-1 $\beta$-activated mast cells

The activation of NF- $\kappa$ B requires phosphorylation and proteolytic degradation of the inhibitory protein $\mathrm{I} \kappa \mathrm{B} \alpha$ [31]. To determine whether the inhibitory activity of

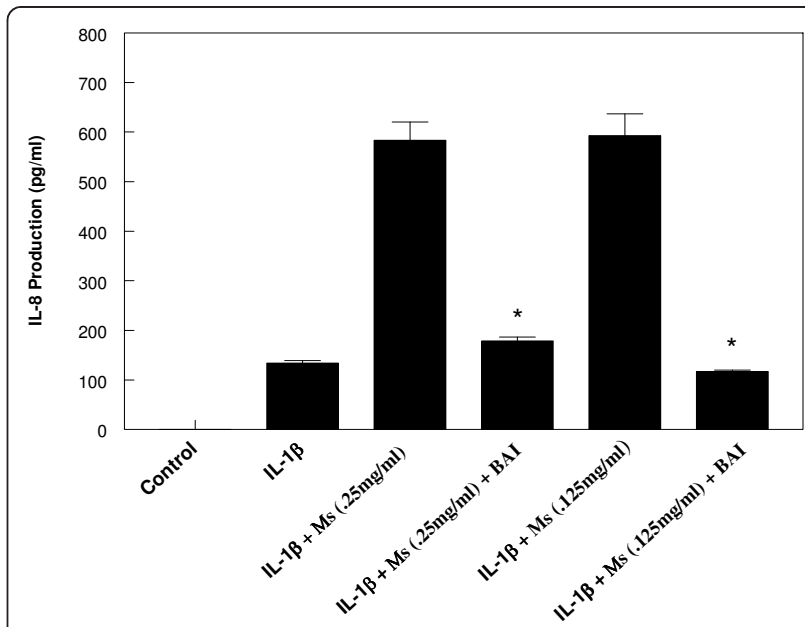

Figure 8 Effects of Baicalein (BAl, $30 \mu \mathrm{M})$ on production of IL-8 from Mainstream cigarette smoke extract (Ms)-treated and IL$1 \beta$-activated HMC-1. ${ }^{*}$ indicates $p<.0005$ when compared with the corresponding IL-1 $\beta+$ Ms groups). 


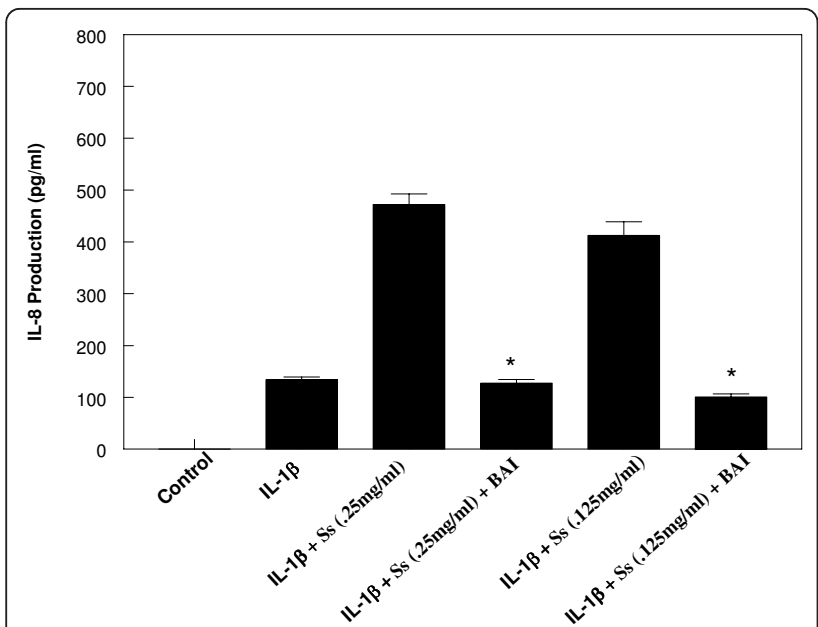

Figure 9 Effects of Baicalein (BAI, $30 \mu \mathrm{M})$ on production of IL-8 from Sidestream cigarette smoke extract (Ss)-treated and IL$\mathbf{1} \beta$-activated HMC-1. (* indicates $p<.0005$ when compared with the corresponding $\mathrm{IL}-1 \beta+\mathrm{Ss}$ groups)
BAI is due to its effect on $\mathrm{I} \kappa \mathrm{B} \alpha$ phosphorylation and degradation, we used Western blot analysis to examine the cytoplasmic levels of $\mathrm{I} \kappa \mathrm{B} \alpha$ in HMC- 1 after treatment with Ms or Ss CSE (both $0.125 \mathrm{mg} / \mathrm{mL}$ ) and IL- $1 \beta$ $(10 \mu \mathrm{g} / \mathrm{mL})$ in the presence or absence of BAI $(30 \mu \mathrm{M})$. The data showed that in the presence of IL-1 $\beta$, the $\mathrm{I} \kappa \mathrm{B} \alpha$ protein levels were decreased in HMC-1 (Figure $12)$. In cell treated with IL-1 $\beta$ and Ms or Ss CSE, the $\mathrm{I} \kappa \mathrm{B} \alpha$ protein levels were further decreased when compared to that of the only IL-1 $\beta$-activated group (Figure $12)$. With the addition of BAI, the $\mathrm{I} \kappa \mathrm{B} \alpha$ protein levels were markedly increased when compared to that of the IL-1 $\beta$ - and CSE-activated HMC-1 (Figure 12).

\section{Discussion}

Inflammatory cytokines are important factors in chronic inflammation, allergy, asthma, atherogenesis, and autoimmune diseases. Human mast cells play an integral role in the inflammatory response by accumulating at

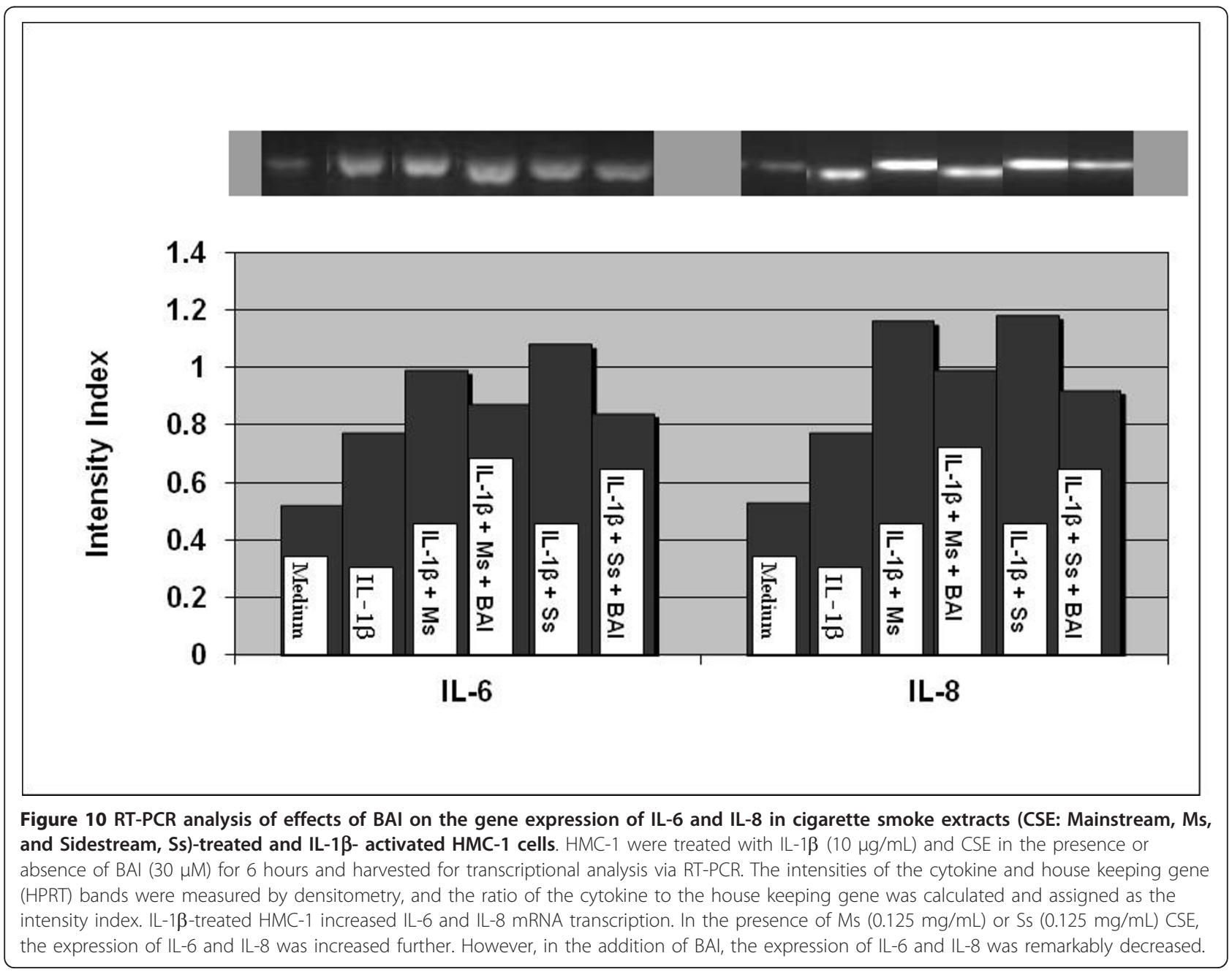



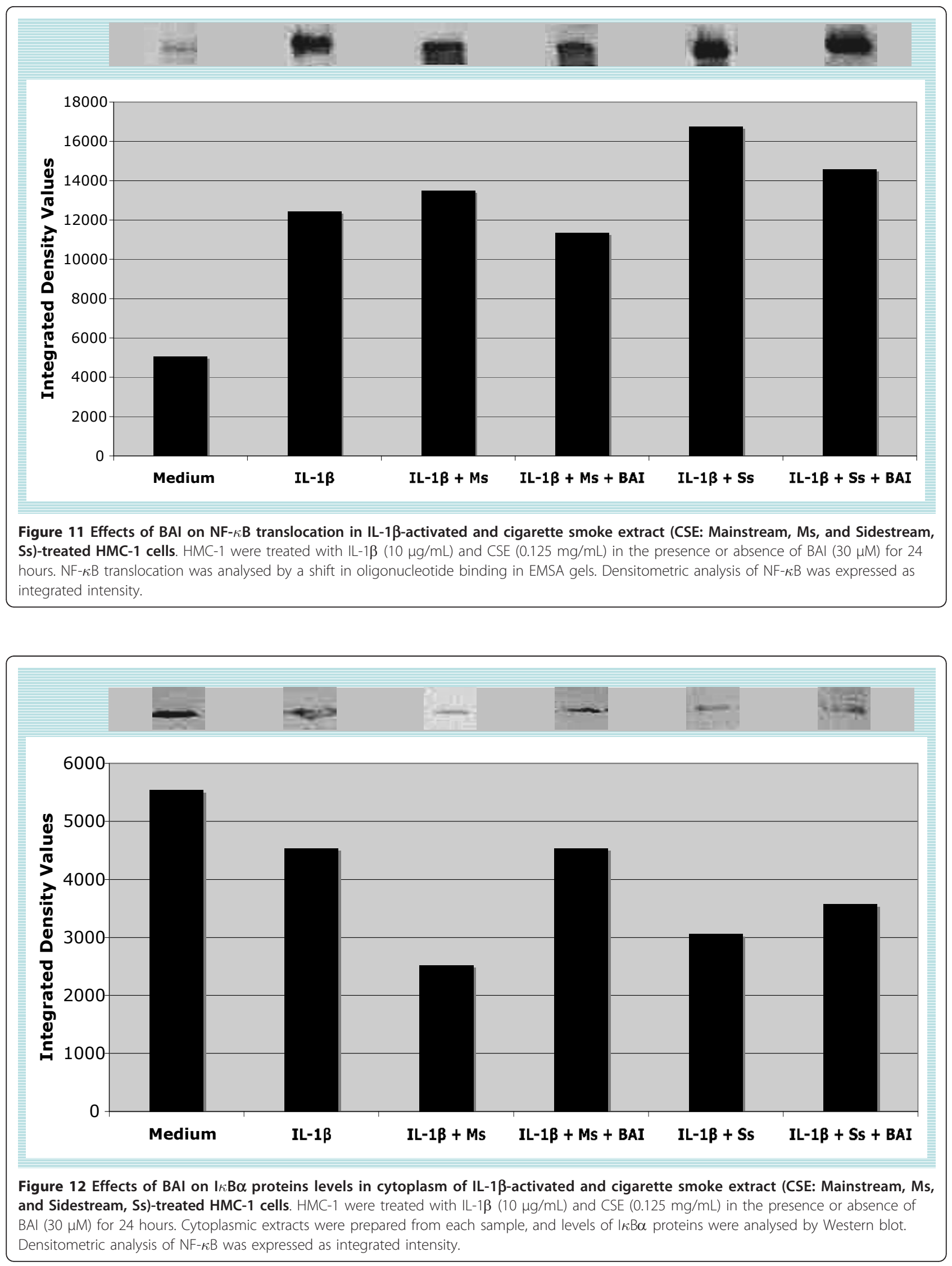
sites of inflammation and mediating the production of inflammatory cytokines, such as IL-6 and IL-8 [32].

IL-6 promotes the formation of acute phase proteins in the liver during the acute phase response and initiates B-cell transformation into plasma cells. IL-8 serves as a chemo-attractant for neutrophils, macrophages, and T-cells.

The expression of various inflammatory cytokines is regulated by transcription factors. The activation of the NF- $\kappa$ B transcription plays an important role in inflammation through its ability to induce the transcription of proinflammatory genes [33]. The NF- $\kappa \mathrm{B}$ exists as a homo- or hetero-dimer comprised of $65-\mathrm{kDa}$ (Rel A or p65) and $50 \mathrm{kDa}$ (p50) DNA-binding proteins, and is a ubiquitously expressed transcription factor that exists in a latent state in the cytoplasm bound to inhibitory proteins, $\mathrm{I} \kappa \mathrm{B} \alpha$. Following an activation stimulus, $\mathrm{I} \kappa \mathrm{B} \alpha$ undergoes degradation, allowing free NF- $\kappa \mathrm{B}$ to localize to the nucleus where it binds to specific recognition elements in the promoter regions of various genes. This can then initiate transcription of cytokines.

Cigarette smoking is linked to cancer, cardiovascular disease, respiratory disease, and other adverse effects such as atherosclerosis [15]. However, the underlying basic mechanisms involved in the processes that lead to diseases induced by cigarette smoke components is not much known. Previously, we have reported that cigarette smoke extract (CSE) significantly increased IL-6 and IL8 production in IL-1 $\beta$-activated human mast cell-1 (HMC-1). In this study, we aimed to examine effects and mechanisms of CSE on the expression of inflammatory cytokines in mast cells.

Our results showed that both Main- and Side-stream CSE increase IL- 6 and IL- 8 production in IL- $1 \beta$-activated mast cells (Figures 1, 2, 3, and 4). Moreover, RT-PCR analysis of the gene expression of the inflammatory cytokines, IL-6 and IL-8, was markedly increased in smoke extract-treated and IL-1 $\beta$-activated HMC-1 (Figure 10). This suggests that the ability of CSE to increase cytokine production is through the increase of cytokine mRNA transcription. Furthermore, CSE increased NF- $\kappa$ B binding activity (Figure 11) and decreased $\mathrm{I} \kappa \mathrm{B} \alpha$ proteins in the cytoplasm of IL-1 $\beta$-activated mast cells (Figure 12). These results suggest CSE enhances the NF- $\kappa \mathrm{B}$ activation via inhibition of $\mathrm{I} \kappa \mathrm{B} \alpha$ phosphorylation and degradation.

In spite of advances in the pharmacological management of the above mentioned chronic inflammatory diseases and symptoms, to discover effective, alternative antiinflammatory reagents is still needed. Several Chinese herbal medicines have anti-bacterial and viral properties and been used for treatment of chronic inflammation. Previously, we have screened several Chinese herbal medicines and found that the compound Baicalein (BAI) isolated from Huangqin (Scutellaria baicalensis Georgi) has a great inhibitory effect on the production of IL-6 from IL-1 $\beta$-activated HMC- 1 in a dose dependent fashion [28]. In this study we further investigate inhibitory effects and mechanisms of BAI on inflammatory cytokine expression from IL- $1 \beta$-activated and CSE-treated human mast cells.

The results showed that BAI $(1.8$ to $30 \mu \mathrm{M})$ significantly inhibited production of IL- 6 and IL- 8 in a dosedependent manner in IL-1 $\beta$-activated HMC-1 (Figure 5). Since BAI $30 \mu \mathrm{M}$ was the most effective concentration, we only used this dose to treat smoke extract-treated and IL-1 $\beta$-activated HMC-1 cells. We found BAI also significantly inhibited production of IL- 6 and IL- 8 in smoke extract-treated and IL-1 $\beta$-activated HMC-1 (Figures 6, 7, 8 , and 9). The cell viabilities of the drug groups and medium control cultures ranged from 90 to $98 \%$. Thus, this inhibitory effect appears not due to the toxic effect of BAI on HMC-1 cells. Moreover, the gene expression, analyzed by RT-PCR, of these inflammatory cytokines was markedly decreased in smoke extract-treated and IL$1 \beta$-activated HMC-1 (Figure 10) when BAI was present. This suggests that the inhibitory effect of BAI on cytokine productions is through the decrease of cytokine mRNA transcription.

Previously, glucocorticoids that have frequently been used for the treatment of inflammatory diseases, allergy, and autoimmune diseases were thought to suppress NF$\kappa \mathrm{B}$ activation. Glucocorticoids induce the transcription of $\mathrm{I} \kappa \mathrm{B} \alpha$, resulting in an enlarged $\mathrm{I} \kappa \mathrm{B} \alpha$ pool, and therefore reduced active NF- $\kappa \mathrm{B}$ in the nucleus [34]. Additionally, 12-lipoxygenase (12-LOX) has been implicated as a mediator of inflammation, atherosclerosis, and cancer [35-37]. Several in vitro studies have suggested 12/15-LOX products to be co-activators of peroxisomal proliferator activating-receptors (PPAR), regulators of cytokine generation, and modulators of gene expression related to inflammation resolution. The dampening effect of PPAR on inflammation is via their inhibitory activity on expression of NF- $\kappa \mathrm{B}$ [38-40]. As BAI is known as a 12-LOX inhibitor, we speculated the mechanism by which BAI inhibited inflammatory cytokines was through the NF- $\kappa \mathrm{B} /$ $\mathrm{I} \kappa \mathrm{B} \alpha$ pathway. Therefore, we analyzed NF- $\kappa \mathrm{B}$ activation and examined the cytoplasmic levels of $\mathrm{I} \kappa \mathrm{B} \alpha$ in $\mathrm{HMC}-1$ after treatment with IL-1 $\beta$ and CSE in the presence or absence of BAI. Our data showed BAI decreased NF- $\kappa$ B binding activity (Figure 11) and increased $\mathrm{I} \kappa \mathrm{B} \alpha$ proteins in the cytoplasm of IL-1 $\beta$-activated and CSE-treated mast cells (Figure 12). The results suggest BAI inhibits the NF$\kappa \mathrm{B}$ activation via inhibition of $\mathrm{I} \kappa \mathrm{B} \alpha$ phosphorylation and degradation.

In recent studies, an important flavonoid, quercetin, has been reported to exert a strong inhibitory effect on the production of IL- $6, \mathrm{MCP}-1$, and histidine decarboxylase (HDC) mRNA transcription from mast cells [41-43]. 
Our results confirmed that BAI, as a flavonoid, could also strongly inhibit production of inflammatory cytokines of IL- 6 and IL-8 from activated mast cells through the decrease of mRNA transcription. Ultimately it is hoped that BAI will be a possible candidate for future development of novel anti-inflammatory therapies.

\section{Conclusions}

Cigarette smoke extract (CSE) significantly increased IL6 and IL- 8 production in IL-1 $\beta$-activated human mast cell-1 (HMC-1). CSE derived increases in cytokine production is due to the increase of cytokine mRNA transcription. Furthermore, CSE increased NF- $\kappa \mathrm{B}$ binding activity and decreased $\mathrm{I} \kappa \mathrm{B} \alpha$ proteins in the cytoplasm of IL-1 $\beta$-activated mast cells. The results may partially explain why cigarette smoke contributes to lung and cardiovascular diseases.

In searching for effective drugs to treat inflammatory related diseases, we found Baicalein from Chinese herbal medicine possessed a strong inhibitory effect on production of selected inflammatory cytokines from human mast cells. The inhibitory mechanism appears to be due to inhibition of NF- $\kappa \mathrm{B}$ activation pathway and $\mathrm{I} \kappa \mathrm{B} \alpha$ phosphorylation and degradation. This inhibitory effect of Baicalein on the expression of inflammatory cytokines indicates its usefulness in the development of novel antiinflammatory therapies.

\section{List of abbreviations}

BAI: Baicalein; CSE: cigarette smoke extract; Ms: mainstream smoke; Ss: Sidestream smoke; EMSA: electrophoretic mobility shift assay; HMC-1: human mast cell-1; IKBa: inhibitor of KB alpha; MCP-1: monocyte chemotactic protein 1; NF-kB: nuclear factor-kappa B

\section{Acknowledgements}

This work was supported in part by The Ruth R. Harris endowment, and Research Development Committee of ETSU.

\section{Author details}

${ }^{1}$ Department of Internal Medicine, James H. Quillen College of Medicine, East Tennessee State University, Johnson City, Tennessee 37614, USA.

${ }^{2}$ Department of Environmental Engineering, National Cheng Kung University, Tainan, Taiwan. ${ }^{3}$ Departmen of Surgery, James $\mathrm{H}$. Quillen College of Medicine, East Tennessee State University, Johnson City, Tennessee 37614, USA.

\section{Authors' contributions}

DSC designed and conducted experiments, analysed data, and wrote the manuscript. TCL and ZDW collected cigarette smoke extract and performed reference search. $\mathrm{KH}$ conducted experiments and proofread manuscript. $\mathrm{TH}$ and $\mathrm{CL}$ contributed to the experiments of EMSA and Western blot. TS conducted experiments and analysed data. GK oversaw research. The authors have had the opportunities to both read and approve the final manuscript.

\section{Competing interests}

The authors declare that they have no competing interests.

Received: 22 December 2011 Accepted: 6 February 2012 Published: 6 February 2012
References

1. Krishnaswamy G, Kelley J, Johnson D, Youngberg G, Stone W, Huang SK Bieber J, Chi DS: The human mast cell: functions in physiology and disease. Front Biosci 2001, 6:D1109-1127.

2. Krishnaswamy G, Ajitawi O, Chi DS: The human mast cell: an overview. Methods Mol Biol 2006, 315:13-34

3. Metz M, Grimbaldeston MA, Nakae S, Piliponsky AM, Tsai M, Galli SJ: Mast cells in the promotion and limitation of chronic inflammation. Immunol Rev 2007, 217:304-328.

4. Igarashi Y, Goldrich MS, Kaliner MA, Irani AM, Schwartz LB, White MV: Quantitation of inflammatory cells in the nasal mucosa of patients with allergic rhinitis and normal subjects. J Allergy Clin Immunol 1995, 95:716-725.

5. Brightling CE, Symon FA, Birring SS, Bradding P, Wardlaw AJ, Pavord ID: Comparison of airway immunopathology of eosinophilic bronchitis and asthma. Thorax 2003, 58:528-532.

6. Garriga MM, Friedman MM, Metcalfe DD: A survey of the number and distribution of mast cells in the skin of patients with mast cell disorders. J Allergy Clin Immunol 1988, 82:425-432.

7. Lee DM, Friend DS, Gurish MF, Benoist C, Mathis D, Brenner MB: Mast cells: a cellular link between autoantibodies and inflammatory arthritis. Science 2002, 297:1689-1692

8. Castells M: Mast cell mediators in allergic inflammation and mastocytosis. Immunol Allergy Clin North Am 2006, 26:465-485.

9. Baumann $H$, Jahreis GP, Sauder DN, Koj A: Human keratinocytes and monocytes release factors which regulate the synthesis of major acute phase plasma proteins in hepatic cells from man, rat, and mouse. J Biol Chem 1984, 259:7331-7342.

10. Okada M, Sakaguchi N, Yoshimura N, Hara H, Shimizu K, Yoshida N, Yoshizaki K, Kishimoto S, Yamamura Y, Kishimoto T: B cell growth factors and $B$ cell differentiation factor from human $T$ hybridomas. Two distinct kinds of B cell growth factor and their synergism in B cell proliferation. $J$ Exp Med 1983, 157:583-590.

11. Hack CE, Aarden LA, Thijs LG: Role of cytokines in sepsis. Adv Immunol 1997, 66:101-195.

12. Cannon JG, Evans WJ, Hughes VA, Meredith CN, Dinarello CA: Physiological mechanisms contributing to increased interleukin-1 secretion. J Appl Physiol 1986, 61:1869-1874

13. Chi DS, Fitzgerald SM, Pitts S, Cantor K, King E, Lee SA, Huang SK, Krishnaswamy G: MAPK-dependent regulation of IL-1- and betaadrenoreceptor-induced inflammatory cytokine production from mast cells: implications for the stress response. BMC Immunol 2004, 5:22.

14. Lee SA, Fitzgerald SM, Huang SK, Li C, Chi DS, Milhorn DM, Krishnaswamy G: Molecular regulation of interleukin-13 and monocyte chemoattractant protein-1 expression in human mast cells by interleukin-1beta. Am J Respir Cell Mol Biol 2004, 31:283-291.

15. Lusis AJ: Atherosclerosis. Nature 2000, 407:233-241.

16. Lin CC, Shieh DE: The anti-inflammatory activity of Scutellaria rivularis extracts and its active components, baicalin, baicalein and wogonin. Am J Chin Med 1996, 24:31-36.

17. Wakabayashi I: Inhibitory effects of baicalein and wogonin on lipopolysaccharide-induced nitric oxide production in macrophages. Pharmacol Toxicol 1999, 84:288-291.

18. Li FQ, Wang T, Pei Z, Liu B, Hong JS: Inhibition of microglial activation by the herbal flavonoid baicalein attenuates inflammation-mediated degeneration of dopaminergic neurons. J Neural Transm 2005, 112:331-347.

19. Woo KJ, Lim JH, Suh SI, Kwon YK, Shin SW, Kim SC, Choi YH, Park JW, Kwon TK: Differential inhibitory effects of baicalein and baicalin on LPS induced cyclooxygenase-2 expression through inhibition of C/EBPbeta DNA-binding activity. Immunobiology 2006, 211:359-368.

20. Cheng PY, Lee YM, Wu YS, Chang TW, Jin JS, Yen MH: Protective effect of baicalein against endotoxic shock in rats in vivo and in vitro. Biochem Pharmacol 2007, 73:793-804.

21. Hsieh CJ, Hall K, Ha T, Li C, Krishnaswamy G, Chi DS: Baicalein inhibits IL$1 \beta$ - and TNF- $\alpha$-induced inflammatory cytokine production from human mast cells via regulation of the NF-kB pathway. Clinical Molecular Allergy 2007, 5:5.

22. Fitzgerald SM, Lee SA, Hall HK, Chi DS, Krishnaswamy G: Human lung fibroblasts express interleukin-6 in response to signaling after mast cell contact. Am J Respir Cell Mol Biol 2004, 30:585-593. 
23. Fitzgerald SM, Chi DS, Hall HK, Reynolds SA, Aramide O, Lee SA, Krishnaswamy G: GM-CSF induction in human lung fibroblasts by IL1beta, TNF-alpha, and macrophage contact. J Interferon Cytokine Res 2003, 23:57-65.

24. Li C, Browder W, Kao RL: Early activation of transcription factor NFkappaB during ischemia in perfused rat heart. Am J Physiol 1999, 276 H543-552.

25. Li C, Ha T, Kelley J, Gao X, Qiu Y, Kao RL, Browder W, Williams DL: Modulating Toll-like receptor mediated signaling by (1- > 3)-beta-Dglucan rapidly induces cardioprotection. Cardiovasc Res 2004, 61:538-547.

26. Li C, Kao RL, Ha T, Kelley J, Browder IW, Williams DL: Early activation of IKKbeta during in vivo myocardial ischemia. Am J Physiol Heart Circ Physiol 2001, 280:H1264-1271.

27. Li C, Ha T, Liu L, Browder W, Kao RL: Adenosine prevents activation of transcription factor NF-kappa B and enhances activator protein-1 binding activity in ischemic rat heart. Surgery 2000, 127:161-169.

28. Hsieh CJ, Hall K, Krishnaswamy G, Chi DS: Differential effects of berberine, baicalein, and triptolide on cytokine production from IL-1 -activated mast cells [abstract]. J Immunol 2007, 178:95.28.

29. Baeuerle PA, Baltimore D: NF-kappa B: ten years after. Cell 1996, 87:13-20

30. Baldwin AS Jr: The NF-kappa B and I kappa B proteins: new discoveries and insights. Annu Rev Immunol 1996, 14:649-683.

31. Baeuerle PA, Baichwal VR: NF-kappa B as a frequent target for immunosuppressive and anti-inflammatory molecules. Adv Immunol 1997, 65:111-137.

32. Henz BM, Maurer M, Lippert U, Worm M, Babina M: Mast cells as initiators of immunity and host defense. Exp Dermatol 2001, 10:1-10.

33. Jobin C, Bradham CA, Russo MP, Juma B, Narula AS, Brenner DA, Sartor RB: Curcumin blocks cytokine-mediated NF-kappa B activation and proinflammatory gene expression by inhibiting inhibitory factor I-kappa B kinase activity. J Immunol 1999, 163:3474-3483.

34. Scheinman Rl, Cogswell PC, Lofquist AK, Baldwin AS Jr: Role of transcriptional activation of I kappa B alpha in mediation of immunosuppression by glucocorticoids. Science 1995, 270:283-286

35. Kuhn H, O'Donnell VB: Inflammation and immune regulation by $12 / 15-$ lipoxygenases. Prog Lipid Res 2006, 45:334-356.

36. George J, Afek A, Shaish A, Levkovitz H, Bloom N, Cyrus T, Zhao L, Funk CD, Sigal $E$, Harats D: 12/15-Lipoxygenase gene disruption attenuates atherogenesis in LDL receptor-deficient mice. Circulation 2001, 104:1646-1650

37. Matsuyama M, Yoshimura R, Mitsuhashi M, Hase T, Tsuchida K, Takemoto Y, Kawahito $Y$, Sano H, Nakatani T: Expression of lipoxygenase in human prostate cancer and growth reduction by its inhibitors. Int J Oncol 2004, 24:821-827.

38. Yuan Z, Liu Y, Liu Y, Zhang J, Kishimoto C, Wang Y, Ma A, Liu Z: Cardioprotective effects of peroxisome proliferator activated receptor gamma activators on acute myocarditis: anti-inflammatory actions associated with nuclear factor kappaB blockade. Heart 2005, 91:1203-1208.

39. Nakajima A, Wada K, Miki H, Kubota N, Nakajima N, Terauchi Y, Ohnishi S, Saubermann LJ, Kadowaki T, Blumberg RS, Nagai R, Matsuhashi N: Endogenous PPAR gamma mediates anti-inflammatory activity in murine ischemia-reperfusion injury. Gastroenterology 2001, 120:460-469.

40. Appel S, Mirakaj V, Bringmann A, Weck MM, Grunebach F, Brossart P: PPARgamma agonists inhibit toll-like receptor-mediated activation of dendritic cells via the MAP kinase and NF-kappaB pathways. Blood 2005, 106:3888-3894.

41. Kempuraj D, Castellani ML, Petrarca C, Frydas S, Conti P, Theoharides TC, Vecchiet J: Inhibitory effect of quercetin on tryptase and interleukin-6 release, and histidine decarboxylase mRNA transcription by human mast cell-1 cell line. Clin Exp Med 2006, 6:150-156.

42. Castellani ML, Kempuraj D, Frydas S, Theoharides TC, Simeonidou I, Conti P, Vecchiet J: Inhibitory effect of quercetin on tryptase and MCP-1 chemokine release, and histidine decarboxylase mRNA transcription by human mast cell-1 cell line. Neuroimmunomodulation 2006, 13:179-186.

43. Kandere-Grzybowska K, Kempuraj D, Cao J, Cetrulo CL, Theoharides TC: Regulation of IL-1-induced selective IL-6 release from human mast cells and inhibition by quercetin. Br J Pharmacol 2006, 148:208-215. doi:10.1186/1476-7961-10-3

Cite this article as: Chi et al:: Enhanced effects of cigarette smoke extract on inflammatory cytokine expression in IL-1 $\beta$-activated human mast cells were inhibited by Baicalein via regulation of the NF- $\kappa$ B pathway. Clinical and Molecular Allergy 2012 10:3.

\section{Submit your next manuscript to BioMed Central and take full advantage of:}

- Convenient online submission

- Thorough peer review

- No space constraints or color figure charges

- Immediate publication on acceptance

- Inclusion in PubMed, CAS, Scopus and Google Scholar

- Research which is freely available for redistribution

Submit your manuscript at www.biomedcentral.com/submit
Biomed Central 